\title{
Pengaruh pemberian yoghurt sinbiotik tanpa lemak ditambah tepung gembili terhadap kadar kolesterol LDL tikus hiperkolesterolemia
}

\author{
Afida Soucha Towil ${ }^{1}$, Adriyan Pramono ${ }^{2}$ \\ ABSTRACT \\ Background: Yoghurt is a fermented milk product, produced by lactic acid bacteria and has being proved to lower \\ cholesterol. The addition lesser yam of inulin in yogurt product could be the hypocholesterolemic effect. \\ Objective: The aim of this study was to analyze the effect of enriched lesser yam inulin into non-fat yoghurt to reduce LDL \\ cholesterol level in hypercholesterolemia rats. \\ Methods: This was an experimental study with randomized control trial (RCT) was conducted to 24 male Wistar rats \\ hypercholesterolemia. The rats were grouped using simple random sampling into 4 groups: control, P1 (consumed 2 ml dose), \\ $P 2$ (consumed $3 \mathrm{ml}$ dose), and P3 (consumed $4 \mathrm{ml}$ dose), each group were contained of 6 rats. Non-fat yoghurt synbiotic \\ enriched with lesser yam inulin were administered for 14 days intervention. LDL cholesterol levels were determined using \\ CHOD-PAP method. Data were analyzed using paired t-test and One Way ANOVA followed by LSD test at 95\% confidence \\ level. \\ Results: LDL cholesterol level was decreased significantly after 14 days intervention $(P 1=16.63 \%(p=0.033)$; $P 2=20.72 \%$ \\ $(p=0.034) ; P 3=20.51 \%(p=0.013))$. P2 was the highest decreasing of LDL cholesterol compared to P3, with the provision of \\ non-fat yoghurt synbiotic enriched with lesser yam inulin for about $3 \mathrm{ml}$. \\ Conclusion: Non-fat yoghurt synbiotic enriched with lesser yam inulin was significant lowering LDL cholesterol level in \\ hypercholesterolemia rats.
}

Key words: non-fat yoghurt synbiotic, LDL cholesterol, hypercholesterolemia, lesser yam

\begin{abstract}
ABSTRAK
Latar Belakang: Yoghurt adalah probiotik produk susu fermentasi. Probiotik yang ditambah prebiotic akan menjadi sinbiotik, yang diduga mampu menurunkan kolesterol LDL lebih baik disbanding probiotik saja. Tepung gembili mengandung inulin sebagai sinbiotik alami. Penambahan inulin tepung gembili bisa menjadi efek hipokolesterolemik.

Tujuan: Penelitian ini bertujuan untuk menganalisis pengaruh non-lemak yoghurt sinbiotik ditambah dengan inulin dari tepung ubi terhadap kadar kolesterol LDL pada tikus hiperkolesterolemia.

Metode: Penelitian eksperimental dengan rancangan randomized control trial (RCT) dilakukan pada 24 tikus Wistar hypercholesterolemia jantan. Tikus dikelompokkan menggunakan simple random sampling. Sampel dibagi menjadi 4 kelompok: kontrol, P1 (dikonsumsi $2 \mathrm{ml}$ dosis), P2 (dikonsumsi $3 \mathrm{ml}$ dosis), dan P3 (dikonsumsi 4 dosis ml), masing-masing kelompok yang terdiri dari 6 tikus. Yoghurt sinbiotik non-lemak ditambahkan dengan inulin ubi diintervensikan selama 14 hari. Kadar kolesterol LDL yang ditentukan dengan menggunakan metode CHOD-PAP. Semua data yang dikumpulkan dianalisis dengan menggunakan paired t-test dan One Way ANOVA dilanjutkan dengan uji LSD pada tingkat kepercayaan $95 \%$.

Hasil: Kadar kolesterol LDL menurun secara signifikan setelah 14 hari intervensi pada kelompok P1 = 16,63\% $(p=0,033)$; $P 2=20,72 \%(p=0,034) ; P 3=20,51 \%(p=0,013)) . P 2$ adalah yang tertinggi penurunan kolesterol LDL dibandingkan dengan P3, dengan pemberian yoghurt sinbiotik non-lemak ditambahkan dengan tepung ubi lebih rendah selama sekitar 3 ml. Kesimpulan: Yoghurt non lemak ditambah sinbiotik inulin dari tepung ubi mampu menurunkan kadar kolesterol LDL dengan bermakna pada tikus hiperkolesterolemia.
\end{abstract}

Kata kunci: sinbiotik, tepung gembili, LDL Kolesterol, yogurt tanpa lemak

\section{PENDAHULUAN}

Penyakit kardiovaskuler merupakan penyebab kematian utama di dunia. Lebih dari $80 \%$ kematian tersebut terjadi di negara berkembang. ${ }^{1}$ Kejadian penyakit kardiovaskuler mencapai $8,01 \%$ pada tahun 2010 di Indonesia. ${ }^{2}$ Salah satu faktor risiko penyakit

${ }^{2}$ Program Studi Ilmu Gizi Fakultas Kedokteran

Universitas Diponegoro, Indonesia

${ }^{2}$ Center of Nutrition Research (CENURE)

Koresponednsi: adriyanpramono@fk.undip.ac.id kardiovaskuler yaitu hiperkolesterolemia. Hiperkolesterolemia merupakan suatu keadaan dimana konsentrasi kolesterol di dalam darah melebihi batas normal. Hiperkolesterolemia terjadi akibat akumulasi kolesterol dan lipid pada dinding pembuluh darah. Kolesterol LDL (Low Density Lipoprotein) yang teroksidasi berperan dalam pembentukan plak aterosklerosis. ${ }^{3}$

Salah satu alternatif yang aman untuk menurunkan kadar kolesterol LDL yaitu modifikasi pola diet. Diet yang dianjurkan adalah dengan mengkonsumsi makanan bersifat hipokolesterolemik. ${ }^{4}$ Yoghurt 
merupakan salah satu produk hasil fermentasi susu dengan media bakteri asam laktat yang mempunyai efek hipokolesterolemik. ${ }^{5,6}$ Yoghurt yang banyak terdapat di pasaran yaitu yoghurt probiotik. ${ }^{7}$ Yoghurt umumnya mengandung paling sedikit 3,25\% lemak susu dan $8,25 \%$ padatan non lemak. Yoghurt tanpa lemak mungkin dibuat, dengan penambahan prebiotik dapat menjadi pangan alternatif untuk makanan hipokolesterolemik. Terdapat efek sinergistik antara probiotik dan prebiotik, yang secara signifikan menurunkan kolesterol. ${ }^{4}$ Kombinasi probiotik dengan prebiotik ini disebut sinbiotik. ${ }^{8}$

Inulin merupakan salah satu prebiotik karena kemampuannya menstimulasi perkembangan bakteri baik yang ada dalam usus. Peran inulin sebagai serat larut dapat membantu menurunkan kadar kolesterol darah. $^{9} \quad$ Indonesia memiliki keanekaragaman tumbuhan yang mengandung inulin. Umbi gembili (Dioscorea esculenta) memiliki kadar inulin sebesar $14,77 \% .^{10}$ Sebuah studi menunjukkan pemberian $18 \mathrm{~g}$ inulin per hari pada pria dan wanita hiperkolesterolemia, dapat menurunkan kadarkolesterol LDL secara signifikan, sebanyak $14.4 \% \% .^{11}$

Penelitian terdahulu yang dilakukan pada tikus wistar hiperkolesterolemia, diperoleh hasil bahwa pemberian susu fermentasi dengan dosis sehari sebesar 2 - $3 \mathrm{ml}$ selama 14 hari mampu menurunkan kadar kolesterol LDL secara bermakna. ${ }^{12}$ Penelitian yoghurt sinbiotik tanpa lemak dengan umbi gembili dalam bentuk tepung sebagai sumber inulin dan pengaruhnya terhadap kadar kolesterol LDL tikus hiperkolesterolemia belum pernah dilakukan, sehingga melalui penelitian ini peneliti ingin mengkaji lebih jauh pengaruh pemberian yoghurt sinbiotik tanpa lemak ditambah tepung gembili terhadap penurunan kadar kolesterol LDL tikus hiperkolesterolemia.

\section{METODE DAN BAHAN}

Penelitian ini merupakan experimental dengan rancangan randomized control trial (RCT). Pemilihan subjek penelitian untuk pengelompokan dan perlakuan dilakukan menggunakan acak sederhana. Intervensi dalam penelitian ini adalah pemberian yoghurt sinbiotik tanpa lemak ditambah tepung gembili. Efek yang diamati adalah kadar kolesterol LDL sebelum dan sesudah intervensi. Sampel penelitian ini menggunakan tikus galur wistar jantan dengan inklusi yaitu 120 - 185 gram pada usia $6-8$ minggu dan kriteria eksklusi yaitu tikus mati saat penelitian berlangsung, tikus mengalami perubahan perilaku (sakit dan kehilangan nafsu makan), dan tikus mengalami penurunan berat badan $10 \%$ dari berat awal.

Penentuan jumlah sampel menggunakan ketentuan WHO, jumlah minimal subyek penelitian adalah 5 ekor/kelompok. ${ }^{13}$ Pada penelitian ini terdapat 4 kelompok yaitu 1 kelompok kontrol dan 3 kelompok perlakuan, sehingga jumlah sampel keseluruhan yang dibutuhkan sebanyak 20 ekor. Untuk mengantisipasi adanya drop-out maka jumlah sampel setiap kelompok perlakuan ditambah 1 ekor dan menjadi 6 ekor/kelompok, sehingga jumlah sampel yang dibutuhkan sebanyak 24 ekor. Kelompok dalam penelitian ini yaitu kelompok kontrol (K) mendapat pakan standar dan pakan hiperkolesterol; kelompok perlakuan 1 (P1) mendapat pakan standar, pakan hiperkolesterol, dan yoghurt sinbiotik tanpa lemak ditambah tepunggembilisebanyak $2 \mathrm{ml} / \mathrm{ekor} / \mathrm{hari}$; kelompok perlakuan 2 (P2) mendapat pakan standar, pakan hiperkolesterol, dan yoghurt sinbiotik tanpa lemak ditambah tepung gembili sebanyak 3 ml/ekor/hari; serta kelompok perlakuan 3 (P3) mendapat pakan standar, pakan hiperkolesterol, dan yoghurt sinbiotik tanpa lemak ditambah tepung gembili sebanyak $4 \mathrm{ml} / \mathrm{ekor} / \mathrm{hari}$ di Laboratorium hewan coba terstandar.

Sebelum intervensi, tikus diaklimatisasi selama 1 minggu dengan diberi pakan standar jenis BR 2 (Broiler Finisher) sebanyak $20 \mathrm{~g} /$ hariserta air minum ad libitum. Setelah itu, tikus dibuat hiperkolesterolemia dengan pemberian pakan hiperkolesterol dari otak sapi kukus sebanyak $2 \mathrm{ml}$ dengan cara sonde serta diberikan pakan standar sebanyak 20 g/hari selama 2 minggu. Yoghurt sinbiotik tanpa lemak ditambah tepung gembili terbuat dari susu skim/tanpa lemak yang difermentasi oleh Lactobacillus bulgaricus dan Streptococcus thermophilus dengan penambahan $13,5 \%$ tepung gembili sebagai sumber inulin. Bahan-bahan yang digunakan dalam pembuatan yoghurt sinbiotik tanpa lemak ditambah tepung gembili adalah susu tanpa lemak segar, susu skim bubuk, inokulum dalam media skim Lactobacillus bulgaricus dan Streptococcus thermophilusserta tepung gembili. Pembuatan tepung dengan cara mengukus umbi gembili setelah itu dipotong kecil - kecil, lalu gembili dijemur, ditumbuk, dan diayak melewati ayakan 80 mesh. Proses pembuatan yoghurt sinbiotik tanpa lemak ditambah tepung gembili dilakukan di Laboratorium gizi.

Pengukuran kolesterol LDL dilakukan melalui 3 tahap: tahap awal atau tahap 1 yaitu setelah 1 minggu pakan standar (aklimatisasi), tahap 2 yaitu setelah 2 minggu pemberian pakan standar + pakan hiperkolesterol, tahap 3 yaitu setelah 2 minggu 
pemberian pakan standar + pakan intervensi. Sampel darah tikus diambil sebanyak $2 \mathrm{ml}$ melalui pleksus retroorbitalis setelah tikus dipuasakan selama 12 jam sebelumnya. Sampel darah tersebut kemudian diletakkan pada tabung dan dipisahkan antara darah dan serum melalui proses sentrifuge. Serum darah kemudian digunakan untuk mengukur kolesterol LDL. Pengukuran kolesterol LDL ditentukan dengan metode CHOP-PAP Enzymatic Colorimeter Test. ${ }^{14}$ Tikus keadaan hiper-kolesterolemia jika kolesterol LDL > 27,2 mg/dl. ${ }^{15}$

Data asupan pakan, berat badan, dan kolesterol LDL diuji normalitas dengan menggunakan uji Shapiro-Wilk. Perbedaan kolesterol LDL pada sebelum dan sesudah pemberian pakan hiperkolesterol maupun pemberian yoghurt sinbiotik tanpa lemak ditambah tepung gembili diuji menggunakan Paired T-test dan Wilcoxon. Analisis pengaruh antar kelompok perlakuan dilakukan dengan uji One way Anova yang dilanjutkan dengan uji LSD (Least Significant Difference) dan Kruskal Walis. Semua uji yang dilakukan menggunakan tingkat kepercayaan $95 \%$.

\section{HASIL}

Asupan pakan subjek dilihat dari sisa pakan yang ada. Sisa pakan ditimbang setiap hari selama penelitian berlangsung. Hasil asupan pakan ini hanya berdasarkan sisa pakan standar saja karena pakan hiperkolesterolemia dan pakan intervensi diberikan melalui sonde dan pakan tersebut dapat dihabiskan
Pada tabel 1 menunjukkan asupan pakan tidak ada beda ( $p>0.05)$. Asupan pakan standar saat aklimatisasi, pemberian pakan hiperkolesterol, dan pakan intervensi dari yang tertinggi sampai terendah yaitu kelompok P1, P2, K, dan P3.

\section{Berat Badan}

Penimbangan berat badan tikus dilakukan tiga hari sekali oleh peneliti. Peningkatan berat badan tikus dapat diketahui dengan menghitung selisih berat badan

Tabel 2 menunjukkan bahwa semua kelompok terjadi peningkatan berat badan pada semua tahap penelitian dan ada perbedaan berat badan pada tahap aklimitasi, hiperkolesterol dan saat diberi yoghurt $(\mathrm{p}<0.05)$. Hasil analisis dengan uji Kruskal Walis menunjukkan tidak ada beda berat badan antara masing-masing kelompok $(\mathrm{p}>0.05)$.

\section{LDL}

Pengambilan darah dilakukan pada semua kelompok perlakuan setelah tahap aklimatisasi, tahap hiperkolesterolemia, dan tahap pemberian yoghurt.

Tabel 3 menunjukkan bahwa pada semua kelompok perlakuan mengalami perubahan kadar kolesterol LDL secara signifikan, namun tidak terdapat perbedaan kadar kolesterol LDL yang signifikan setelah pemberian pakan tinggi kolesterol antar kelompok perlakuan $(\mathrm{p}>0.05)$.

Tabel 1. Nilai Rerata dan Simpang Baku Asupan Pakan Tikus

\begin{tabular}{lccccc}
\hline Kelompok & N & $\begin{array}{c}\text { Aklimatisasi } \\
\text { Rerata } \pm \text { SB }\end{array}$ & $\begin{array}{c}\text { Hiperkolesterol } \\
\text { Rerata } \pm \text { SB }\end{array}$ & $\begin{array}{c}\text { Intervensi } \\
\text { Rerata } \pm \text { SB }\end{array}$ & $\begin{array}{c}\text { Hiperkoles- } \\
\text { Yoghurt }\end{array}$ \\
\hline K & 6 & $19.48 \pm 0.71$ & $19.62 \pm 0.48$ & $19.67 \pm 0.20$ & $0.917^{*}$ \\
P1 & 6 & $19.95 \pm 0.12$ & $19.95 \pm 0.06$ & $19.82 \pm 0.27$ & $0.109^{*}$ \\
P2 & 6 & $19.86 \pm 0.28$ & $19.57 \pm 0.44$ & $19.71 \pm 0.34$ & $0.345^{*}$ \\
P3 & 6 & $19.60 \pm 0.64$ & $19.88 \pm 0.21$ & $19.63 \pm 0.28$ & $0.138^{*}$ \\
\hline
\end{tabular}

*uji beda wilcoxon

Tabel 2. Nilai Rerata dan Simpang Baku Berat Badan Tikus

\begin{tabular}{lcccccc}
\hline Kelompok & $\mathrm{N}$ & $\begin{array}{c}\text { Aklimatisasi } \\
\text { Rerata } \pm \text { SB }\end{array}$ & $\begin{array}{c}\text { Hiperkolesterol } \\
\text { Rerata } \pm \text { SB }\end{array}$ & $\begin{array}{c}\text { Intervensi } \\
\text { Rerata } \pm \text { SB }\end{array}$ & $\begin{array}{c}\text { Hiperkoles- } \\
\text { Yoghurt }\end{array}$ & $\begin{array}{c}\text { Pruskal } \\
\text { Walis }\end{array}$ \\
\hline K & 6 & $155.6 \pm 25.98$ & $211.5 \pm 25.61$ & $230.5 \pm 29.0$ & $0.002^{*}$ & 0.079 \\
P1 & 6 & $155.8 \pm 7.02$ & $219.1 \pm 14.77$ & $241.6 \pm 26.64$ & $0.020^{*}$ & \\
P2 & 6 & $161.5 \pm 16.83$ & $211.0 \pm 21.14$ & $224.5 \pm 23.56$ & $0.027^{*}$ & \\
P3 & 6 & $152.1 \pm 3.12$ & $212.8 \pm 11.65$ & $241.8 \pm 9.17$ & $0.000^{*}$ & \\
\hline
\end{tabular}

*uji beda paired t-test 
Tabel 3. Rerata dan Simpang Baku Kadar Kolesterol LDL Sebelum dan Sesudah Pemberian Pakan Tinggi Kolesterol selama 14 Hari

\begin{tabular}{lcccccc}
\hline LDL & $\mathrm{N}$ & Sebelum $(\mathrm{mg} / \mathrm{dl})$ & Sesudah $(\mathrm{mg} / \mathrm{dl})$ & $\mathrm{p}^{*}$ & $\begin{array}{c}\text { Peningkatan } \\
(\mathrm{mg} / \mathrm{dl})(\%)\end{array}$ & $\begin{array}{c}\text { P } \\
\text { ANOVA }\end{array}$ \\
\hline $\mathrm{K}$ & 6 & $23.58 \pm 5.38$ & $28.13 \pm 4.28$ & .006 & $4.55 \pm 2.45(19.92)$ & .235 \\
P1 & 6 & $28.05 \pm 8.41$ & $35.05 \pm 11.50$ & .027 & $7.00 \pm 5.53(24.95)$ & \\
P2 & 6 & $20.98 \pm 4.76$ & $29.65 \pm 6.33$ & .003 & $8.66 \pm 3.81(41.32)$ & \\
P3 & 6 & $24.11 \pm 5.94$ & $32.90 \pm 6.56$ & .000 & $8.78 \pm 1.57(36.45)$ & \\
\hline
\end{tabular}

*uji beda paired t test

Tabel 4. Rerata dan Simpang BakuKadar Kolesterol LDL Sebelum dan Sesudah Pemberian Yoghurt Sinbiotik Tanpa Lemak ditambah Tepung Gembili selama 14 hari

\begin{tabular}{lrrrccc}
\hline LDL & $\mathrm{N}$ & Sebelum $(\mathrm{mg} / \mathrm{dl})$ & Sesudah $(\mathrm{mg} / \mathrm{dl})$ & $\mathrm{p}^{*}$ & $\begin{array}{c}\text { Penurunan } \\
(\mathrm{mg} / \mathrm{dl})\end{array}$ & $\begin{array}{c}\text { P } \\
\text { ANOVA }\end{array}$ \\
\hline K & 6 & $28.13 \pm 4.28$ & $28.36 \pm 5.86$ & .849 & $0.23 \pm 2.85(-0.09)$ & .039 \\
P1 & 6 & $35.05 \pm 11.50$ & $30.05 \pm 12.96$ & .033 & $5.00 \pm 4.17(16.63)$ & \\
P2 & 6 & $29.65 \pm 6.33$ & $24.56 \pm 4.48$ & .034 & $5.08 \pm 4.30(20.72)$ & \\
P3 & 6 & $32.90 \pm 6.56$ & $27.30 \pm 9.59$ & .013 & $5.60 \pm 3.65(20.51)$ & \\
\hline
\end{tabular}

"uji beda paired t test

Tabel 4 menunjukkan bahwa pemberian yoghurt sinbiotik tanpa lemak ditambah tepung gembili di berbagai dosis menyebabkan perubahan yang signifikan pada kadar kolesterol LDL di semua kelompok intervensi (P1, P2, dan P3).Kenaikan kadar kolesterol LDL terjadi pada kelompok kontrol meskipun kenaikannya tidak signifikan. Perbedaan signifikan terbukti secara statistik pada penurunan kadarkolesterol LDL antar kelompok perlakuan setelah pemberian yoghurt sinbiotik tanpa lemak ditambah tepung gembili $(\mathrm{p}<0.05)$. Penurunan kadar kolesterol LDL paling tinggi terjadi pada kelompok $\mathrm{P} 2$ yang mendapat yoghurt sebanyak $3 \mathrm{ml}$.

\section{PEMBAHASAN}

Tikus dikatakan dalam keadaan hiperkolesterolemia jika kolesterol LDL > 27,2 mg/dl. ${ }^{15}$ Pemberian pakan tinggi lemak berupa otak sapi pada hewan cobasebanyak $2 \mathrm{ml}$ per hari selama 14 hari. Pemberian otak sapi dengan dosis tersebut dapat meningkatkan kadar kolesterol LDL dengan rata-rata kenaikan mencapai $68 \%{ }^{16}$ Pemberian pakan tinggi lemak sebanyak $2 \mathrm{ml} /$ hari ke tikus dengan cara di sonde diharapkan mampu meningkatkan kadar kolesterol LDL. Pakan tinggi kolesterol yang digunakan adalah otak sapi kukus dengan kandungan kolesterol 3100 mg per $100 \mathrm{~g}$, asam lemak jenuh $2 \%$, dan lemak trans $1 \% .{ }^{17}$ Berdasarkan penelitian, pemberian otak sapi kukus sebanyak $2 \mathrm{ml} /$ hari dapat meningkatkan kadar kolesterol LDL,namun dalam penelitian ini otak sapi kukus hanya mampu meningkatkan kadar kolesterol LDL sampai menjadi hiperkolesterolemia sebanyak 17 tikus yaitu 4 ekor pada kelompok kontrol, P1, dan P2 serta 5 ekor di kelompok P3. Hal ini di karenakan kadar kolesterol LDL sebelum pemberian pakan tinggi lemak pada 7 ekor tikus yang lain cenderung kecil. Akan tetapi pada Tabel 3 menunjukkan adanya perubahan kadar kolesterol LDL yang signifikan setelah pemberian pakan tinggi kolesterol selama 14 hari di semua kelompok perlakuan. Peningkatan kadar kolesterol LDL pada setiap kelompok perlakuan setelah pemberian otak sapi adalah $\geq 19.92 \%$.

Mekanisme hiperkolesterolemia dimulai dari asupan lemak jenuh dan kolesterol yang berasal dari otak sapi akan dicerna di dalam usus halus sehingga menghasilkan asam lemak bebas, trigliserida, fosfolipid, dan kolesterol. Selanjutnya senyawasenyawa tersebut diubah menjadi kilomikron setelah diserap oleh usus. Terdapat sisa pemecahan kilomikron berbentuk kolesterol bebas bersama dengan apoprotein membentuk VLDL(Very Low Density Lipoprotein). Selanjutnya enzim lipoprotein lipase sel endotelial mengubah VLDL menjadi IDL 
(Intermediate Density Lipoprotein) yang bertahan selama 2-6 jam sebelum berubah menjadi LDL. ${ }^{18}$

Tabel 4 menunjukkan adanya perubahan kadarkolesterol LDL yang signifikan setelah pemberian yoghurt sinbiotik tanpa lemak ditambah tepung gembili pada semua kelompok intervensi. Masing-masing dosisyoghurt sinbiotik tanpa lemak ditambah tepung gembili memberikan penurunan yang signifikan terhadap kadar kolesterol LDL, sedangkan kelompok kontrol mengalami kenaikan kadar kolesterol LDL meskipun tidak signifikan. Penurunan kadar kolesterol LDL paling tinggi terjadi pada kelompok P2 yang mendapatkan yoghurt sinbiotik tanpa lemak ditambah tepung gembilisebanyak $3 \mathrm{ml}$ yaitu $20.72 \%$.Hasil analisis perubahan kadar kolesterol LDL menunjukkan terdapat perbedaan yang signifikan antar kelompok K, $\mathrm{P} 1, \mathrm{P} 2$, dan $\mathrm{P}$.

Inulin sebagai prebiotik dan bakteri asam laktat Streptococcus thermophilus serta Lactobacillus bulgaricus yang terdapat pada yoghurt sinbiotik tanpa lemak mempengaruhi penurunan kadar kolesterol LDL. ${ }^{9}$ Berdasarkan penelitian sebelumnya diketahui bahwa dalam $100 \mathrm{ml}$ yoghurt sinbiotik tanpa lemak dengan penambahan tepung gembili terkandung $0,08 \%$ serat. ${ }^{19}$ Mekanisme penurunan kolesterol LDL oleh inulin adalah efek hipotrigliseridadariinulin melalui penghambatanaktivitasenzimlipogenik di hati sehingga menyebabkansintesistrigliserida berkurang. Penurunan produksi trigliserida menyebabkan penurunan sekresi VLDL. Penurunan sintesis dan sekresi VLDL dalam hati yang akan berdampak pada menurunnya kadar LDL kolesterol serum, karena setelah trigliserida dipecah, VLDL akan membentuk menjadi IDL (Intermediate Density Lipoprotein)/ sisa VLDL. IDL/sisa VLDL dapat diserap oleh hati secara langsung melalui reseptor LDL atau dapat di ubah menjadi LDL. ${ }^{20-24}$

Berdasarkan penelitian sebelumnya diketahui bahwa jumlah bakteri asam laktat yang terkandung dalam yoghurt sinbiotik tanpa lemak dengan penambahan gembili adalah $7 \pm 6,52 \times 10^{7}$ $\mathrm{cfu} / \mathrm{ml} .{ }^{19}$ Yoghurt merupakan probiotik yangdalam fermentasinya menggunakan bakteri asam laktat. Konsumsi probiotikyang di dalamnya mengandung bakteri asam laktat akan menjadi metode alami untuk menurunkan kadar kolesterol darah. ${ }^{25,5,6}$ Mekanisme probiotik dalam penurunan LDL adalah Inulin mengalami proses fermentasi oleh probiotik menghasilkan asam lemak rantai pendek berupa asam propionat. Asam propinat menurunkan sintesis kolesterol dihati dengan menghambat kerja enzim $H M G C o A$ reductase. Enzim HMGCoA reductase berperan dalam sintesis kolesterol di hati. Penurunan produksi kolesterol akan menghambat sintesis dan sekresi VLDL. Penurunan sintesis dan sekresi VLDL dapat menurunkan kadar LDL karena LDL adalah produk metabolisme VLDL. ${ }^{26,21,24}$

\section{SIMPULAN}

Pemberian yoghurt sinbiotik tanpa lemak ditambah tepung gembili pada kelompok P2 sebanyak $3 \mathrm{ml}$ dapat menurunkan kadar kolesterol LDL terbesar yaitu $20.72 \%$.

\section{DAFTAR PUSTAKA}

1. Mendis S, Puska P, Norrving B. Global Atlas on Cardiovascular Disease Prevention and Control. World Health Organization. 2011. Geneva.

2. Soepardi J. Gambaran Penyakit Tidak Menular di Rumah Sakit di Indonesia Tahun 2009 dan 2010. Pusat Data dan Informasi Kementrian Kesehatan RI. 2012.

3. Albert AD, Battaglia KB. The Role of Cholesterol in Rod Outer Segment Membranes. Progress in Lipid Research 2005;44:99-124.

4. Varady KA, Jones PJH. Combination Diet and Exercise Inteventions for the Treatment of Dyslipidemia: an Effective Preliminary Strategy to Lower Cholesterol Levels. J.Nutr. 2005;135:1829-35.

5. Akoma O, Elekwa UO, Afodunrinbi AT, Onyeukwu GC. Yogurtfrom Coconut dan Tigernuts. J. Food Technol Afr. 2000;5(4):132-4.

6. Lovita A. Pengaruh Imbangan Bakteri Lactobacillus bulgaricus,Streptococcus thermophillus, Lactobacillus acidophillus dan Bifidobacterumdalam Yoghurt terhadap Kandungan Kolesterol Darah pada Mencit. 2003. Bandung.

7. Nakamura Y, Kaihara A, Yoshii K, Tsumura Y, Ishimitsu S, Tonogai Y. Content and Composition of Isoflavonoids in Mature or Immature Beans and Bean Sprouts Consumed in Japan. Journal of Health Science 2001;47(4):394406.

8. Alonso JL, Vaquez MJ, Dominguez H, Parajo JC. Xylooligosaccharides: Manufacture and Aplication, J. Food Science and Technology 2001;11:387-93.

9. Zainuddin A, Wasito BE, Puspaningsih TNN. Pengujian in Vitro Xiloologosakarida sebagai Kandidat Prebiotik. 2008;14:101-11. 
10. Utami R, Widowati E, Dewati RA. Kajian Penggunaan Tepung Gembili (Dioscorea esculenta) dalam Pembuatan Minuman Sinbiotik terhadap Total Bakteri Probiotik, Karakter Mutu, dan Karakter Sensoris. Jurnal Teknosains Pangan 2013;2(3):3-8.

11. Davidson MH, Maki KC. Effects of Dietary Inulin on Serum Lipids. J. Nutr.1999;129:14747.

12. James W. Anderson, Gilliland Stanley E. Effect of Fermented Milk (Yogurt) Containing Lactobacillus Acidophilus L1 Serum Cholesterol in Hypercholisterolemic Humans. J. of the American College of Nutrition 1999;18(1):43-50.

13. World Health Organization (WHO).General Guidelines for Metodologies on Search and Evaluation of Traditional Medicine. 2001. Geneva.

14. Julyasih KSM. Tepung Rumput Laut Menurunkan Kadar LDL (Low Density Lipoprotein) Plasma Tikus Wistar Hiperkolesterolemia. REKAPANGAN 2012;6(1):8-12.

15. Riesanti DG, Padaga MC, Herawati. Kadar HDL, Kadar LDL dan Gambaran Histopatologi Aorta pada Hewan Model Tikus (Rattus norvegicus) Hiperkolesterolemia dengan Terapi Ekstrak Air Benalu Mangga (Dendrophthoe pentandra). Malang: Universitas Brawijaya.

16. Slamet S. 2008. Pengaruh Pemberian Yoghurt Kedelai Hitam (Black Soyghurt) terhadap Profil Lipid Tikus Hiperkolesterolemia [Skripsi]. Semarang: Universitas Diponegoro.

17. Condé Nast. Nutrition Facts: Beef, Variety Meats and by-Products, Brain, Cooked, Simmered. 2014. Available from URL: http://nutritiondata.self.com/facts/beefproducts $/ 3463 / 2$.

18. Brata HW. 2009. Hubungan Pola Makan, Obesitas, Keteraturan Berolahraga dan Kebiasaan Merokok dengan kejadian Hiperkolesterolemia [Skripsi]. Semarang: Universitas Muhammadiyah Semarang.

19. Karlina R. 2013. Potensi Yoghurt Tanpa Lemak dengan Penambahan Tepung Pisang dan Tepung Gembili sebagai Alternatif Menurunkan Kolesterol [Skripsi].Semarang: Universitas Diponegoro.

20. Kathleen MB, Peter AM. Metabolisme Asilgliserol \& Sfingolipid. Dalam: Murray RK, Granner DK, Mayes PA, Rodwell VW, editor. Biokimia Harper. $27^{\text {th }}$ ed. Jakarta: EGC; 2009:225-37.
21. Beylot M. Effects of Inulin-Type Fructans on Lipid Metabolism in Man and in Animal Models. France. J.Nutr. 2005; 93:163-168.

22. Letexier D, Diraison F, Beylot M. Addition of Inulin to a Moderately High-Carbohydrate Diet Reduces Hepatic Lipogenesis and Plasma TriacylglycerolConcentrations in Humans. Am J Clin Nutr. 2003;77:559-64.

23. Nasar ES, Ismail MG, El Damarawi AM, El Din AA. Effect of Inulin on Metabolic Changes Produced by Fructose Rich Diet. Life Sci J. 2013;10(2):1807-14.

24. Zulkarnain P. 2006. Pengaruh Pemberian Vitamin C terhadap Kadar LDL dan HDL Kolesterol Serum Tikus Wistar Jantan Hiperlipidemia setelah Perlakuan Jus Lidah Buaya [Skripsi].Semarang: Universitas Diponegoro.

25. Baroutkoub A, Mehdi ZR, Belglarian, Hassan J, Zahra S, Mohammad SM, et al. Effects of Probiotic Yoghurt Consumption on The Serum Cholesterol Levels in Hypercholestromic Cases in Shiraz Southern Iran. Scientific Research and Essays 2010;5(16):2206-9.

26. Kaur N, Gupta AK. Applications of Inulin and Oligofructose in Health and Nutrition. J. Biosci. 2002;27:703-14. 